\title{
EDUCATION AND INCOME INEQUALITY IN TURKEY: NEW EVIDENCE FROM PANEL DATA ANALYSIS
}

\author{
Esra ÖZTÜRK ${ }^{[*]}$ \\ Ayşegül KAYAOĞLU ${ }^{[* *]}$
}

\begin{abstract}
Income gini coefficient shows that income inequality has a downward trend in Turkey between 2008 and 2013. As it is expected, the east part of Turkey has higher income distortions, while Marmara and Black Sea regions have relatively lower income Gini coefficients. In this paper, we also computed education Gini at the provincial level from 2008 to 2013. Similar to the income Gini index, the education Gini coefficient is also higher in Eastern and South-eastern regions. Besides, the data show that the provinces that have more equal education distribution are generally located in the Marmara and Central Anatolia regions. In this study, we examine the impact of education inequality on income inequality by analysing provincial level panel data between 2008 and 2013. We have employed both static and dynamic panel data models and also controlled for the endogeneity problem. Econometric analysis provides evidence for a negative association between education Gini coefficient and income inequality.
\end{abstract}

Keywords: Income Inequality, Education Inequality, Gini coefficient, Turkey

JEL Classification: O15, I24, C33

\section{TÜRKİYE’DE EĞİTIMM VE GELİR EŞİTSİZLIĞİ: PANEL VERİ ANALİİ İLE YENİ BULGULAR}

\section{Özet}

Gelir eşitsizliği katsayısı Türkiye’de 2008 ile 2013 yılları arasında azalan bir trend göstermektedir. Beklenildiği gibi Türkiye’nin doğusunda gelir eşitsizliği, Marmara ve Karadeniz bölgelerine kıyasla daha fazladır. Bu çalışmada 2008-2013 yılları arasında il bazında eğitim eşitsizliği katsayısı da hesaplanılmıştır. Gelir eşitsizliği indeksinde olduğu gibi, Doğu ve Güneydoğu bölgeleri eğitim eşitsizliğinin de daha fazla olduğu bölgeler olarak tespit edilmiştir. Ayrıca eğitim eşitsizliğinin daha az olduğu illerin genellikle Marmara ve İç Anadolu bölgelerinde olduğu gözlemlenmektedir. Bu çalışmada eğitim eşitsizliğinin gelir eşitsizliği üzerindeki etkisi il bazında veri kullanılarak 2008-2013 dönemi için analiz edilmiştir.

[*] PhD Student, Koç University, Department of Economics. ozturk.esra@outlook.com

[**] Assist. Prof., Istanbul Technical University, Department of Economics, kayaogluyilmaz@itu.edu.tr 
Ampirik analizde statik ve dinamik panel veri metodlarının yanı sıra olası içsellik sorununa uygun ampirik modeller de kullanılmıştır. Ampirik analiz neticesinde Türkiye’de 2008-2013 yılları arası dönemde gelir eşitsizliği ile eğitim eşitsizliği arasında olumsuz bir ilişki olduğu tespit edilmiştir.

Anahtar Kelimeler: Gelir Eşitsizliği, Eğitim Eşitsizliği, Gini katsayısı, Türkiye

JEL Sinıflaması: O15, I24, C33

\section{Introduction}

The role of human capital investment on the economic growth is widely studied in the literature. Not only its direct effect on the economic development and growth but also its spillover effect on social welfare makes researchers analyse the role of education (educational inequality, especially) on the economy. The unequal opportunities for schooling causes distortions in the distribution of education and recent studies show that education inequality is of a great deal in most of the developing countries, especially through its direct effect on human capital and income growth ${ }^{1}$.

Lopez, Thomas and Wang ${ }^{2}$ present the positive effect of the stock of human capital on the economic growth for 12 countries between 1970 and 1994. Kayaoglu and $\mathrm{Naval}^{3}$ shows that higher investment in human capital contributes to the formation of a growth backlog for Sub-Saharan African countries. Castello and Domenech ${ }^{4}$ try to explain the effect of education on income and, using a data for 108 countries, show that human capital inequality has a negative effect on economic growth rates as expected. O'Neill ${ }^{5}$ shows that in Europe and developed countries, convergence in education levels leads a decrease in income inequality although the same pattern does not exist for world as a whole. The results imply that industrialized countries keep ahead of less developed countries. Moreover, similar to converting income Gini into educational Gini, Thomas, Wang and Fan ${ }^{6}$ convert Kuznets Curve into the Education Kuznets Curve and, they find a U-shape relationship between standard deviation of schooling and average years of schooling. A panel data analysis for large range of countries from 1965 to 1990 show that higher levels of education attainment leads to more equal income distribution as it lowers the income Gini coefficient. In addition, reduction in educational dispersion by one standard deviation decreases income inequality by 0.02 . This implies that education inequality is positively correlated with income Gini index, as it is also suggested by Park ${ }^{7}$. Furthermore, Földvari and Leeuwen ${ }^{8}$ analyse a data

1 Castelló A. and Doménech R., "Human Capital Inequality and Economic Growth: Some New Evidence", The Economic Journal. Vol. 112, No. 478, Conference Papers, 2002, pp. C187-C200.

2 Lopez R., Thomas V. and Wang Y., "Addressing the Education Puzzle: The Distribution of Education and Economic Reform”, Policy Research Working Paper No: 2031. The World Bank, Washington, D.C., 1998.

3 Kayaoglu, A. and Naval J., "Urbanization, Education and the Growth Backlog of Africa", forthcoming.

4 Castelló A. and Doménech R, Ibid.

5 O’Neill D., "Education and Income Growth: Implications for Cross-Country Inequality", Journal of Political Economy. Vol. 103, No. 6, 1995, pp. 1289-1301.

6 Thomas V., Wang Y. and Fan X., "Measuring Education Inequality: Gini Coefficients of Education", Policy Research Working Paper No: 2525. The World Bank, Washington, D.C., 2001.

7 Park K. H., "Educational Expansion and Educational Inequality on Income Distribution, Economics of education Review", Vol. 15, No. 1, 1996, pp. 51-58.

8 Földvari P. and Van Leeuwen B., "Educational and Income Inequality in Europe, ca. 1870-2000", Cliometrica. 8, 
from 1870 to 2000 . A Kuznets-type relationship is constructed with using only Gini coefficients and unexpected results are obtained. The data is separated into two categories as before and after 1950 and it is found that the results of analysis for the two categories are very different from each other. Before 1950, there is a positive relationship between educational Gini and income Gini coefficients and inverted U-curve is obtained. After 1950, the relationship changes into normal $\mathrm{U}$-curve and the results show a negative relationship between two Gini variables. This change in the direction is explained as a result of increased skill premium caused by an increase demand for skill after 1950s. Analysing a panel data from 1965 to 1990, Gregorio and Lee ${ }^{9}$ show that there is a positive effect of education inequality on income distribution. Similar to the articles of Földvari and Leeuwen ${ }^{10}$ and Gregorio and Lee ${ }^{11}$, the correlation between the distribution of education and the distribution of incomes is also analysed by Checchi ${ }^{12}$. The panel data analysis is performed to analyse the relationship between educational and income Gini coefficients of 94 countries from 1960 to 1995 . It concludes that education inequality is negatively correlated with income inequality. Furthermore, the analysis indicates that there is a U-shaped relationship between income inequality and average years of schooling with a turning point at 6.5 years. Thus, it is clear that despite the undeniable negative effect of education inequality on per capita income or income growth, its impact on income inequality is rather inconclusive in the literature.

This relationship between education and income inequality, however, is scarcely studied in Turkey although it has still relatively higher income inequality compared to most of OECD countries and developing economies ${ }^{13}$ and is the third country in the rankings of unequal income distributions after Chile and Mexico in $2011^{14}$. Moreover, the existing literature is also providing ambiguous results for the relationship between income and education inequality in Turkey. Education inequality in the literature is generally measured by using education Gini coefficient at the regional level. These researches show that east part of the country has more unequal education distribution, while western regions have lower education distortions. Güngör ${ }^{15}$, for example, analyse the relationship between education inequality and economic growth in Turkey using a panel data for years between 1975 and 2000 and, finds a U-shaped relationship between the two.

This paper aims to understand the effect of educational inequality on income distribution in Turkey through analysing a panel data at provincial level for the period between 2008 and 2013. The structure of the paper is as follows: Section 2 describes the data and presents the stylized facts. Section 3 provides the empirical results and, Section 4 concludes.

2014, pp.271-300.

9

Gregorio J. D. and Lee J.-W., "Education and Income Inequality: New Evidence from Cross-Country Data”, Review of Income and Wealth. Series. 48, No. 3, 2002.

10

Földvari and Van Leeuwen, Ibid

Gregorio and Lee, Ibid.

12 Checchi D., "Education, Inequality and Income Inequality. Distributional Analysis", Research Programme Discussion Paper. No: DARP 52. The Toyota Centre, London, 2001.

OECD Factbook, Economic, Environmental and Social Statistics, OECD Publishing. OECD, Paris, 2014.

Selim R., Günçavdı Ö. And Bayar A.A., “Türkiye’de Bireysel Gelir Dağılımı Eşitsizlikleri: Fonksiyonel Gelir Kaynakları ve Bölgesel Eşitsizlikler”, TÜsİAD Report No: TÜSİAD-T/2014-06/554. TÜSİAD, İstanbul, 2014.

15 Güngör N. D. "Education, Human Capital Inequality and Economic Growth: Evidence from Turkey", Regional and Sectoral Economic Studies, Vol. 10-2, 2010. 


\section{Data and Stylized Facts}

A panel dataset including income Gini and education Gini indices, per capita value added, labor force participation ratio, number of students in secondary school, population, total budget expenditure of public authorities on education and some demographic variables such as male population ratio, crude divorce rate, number of births, crude marriage rate and crude suicide rate, will be used in the empirical analysis. Tables A.1 to A.6 in the Appendix provides the descriptive statistics for each variable. While income Gini index is at NUTS-1 level and per capita value added data is at NUTS-2 level, other variables are all at the provincial level. The data, which are in NUTS-1 or NUTS-2 level, are expanded to provincial level by considering the region the provinces belong to. ${ }^{16}$ The dataset contains yearly macro data between 2008 and 2013 and, there are officially 81 provinces in that period of time in Turkey.

When the descriptive statistics of income Gini coefficient provided in the Table 1 is analysed, it can be seen that income Gini in Turkey has a decreasing trend. While North East Anatolia region has the highest income Gini value, 0.436, in 2008, Mediterranean region has relatively lower but still the high value, 0.399, in 2013. Figure 1 shows that Mediterranean and East Anatolia regions have the greater income inequality levels in general.

Table I: Descriptive statistics of income Gini coefficient by year

\begin{tabular}{cccccc} 
Income Gini & $\begin{array}{c}\text { Obs. } \\
\text { Number }\end{array}$ & Mean & $\begin{array}{c}\text { Standard } \\
\text { Dev. }\end{array}$ & Min & Max \\
\hline 2008 & 81 & 0,376 & 0,030 & 0,331 & 0,436 \\
2009 & 81 & 0,390 & 0,019 & 0,359 & 0,415 \\
2010 & 81 & 0,375 & 0,028 & 0,327 & 0,417 \\
2011 & 81 & 0,373 & 0,033 & 0,326 & 0,427 \\
2012 & 81 & 0,366 & 0,026 & 0,309 & 0,407 \\
2013 & 81 & 0,359 & 0,029 & 0,315 & 0,399 \\
\hline
\end{tabular}

\section{Source: TURKSTAT, Income and Living Conditions Survey.}

16 Extension from Nuts levels to provincial level is done by considering the regions that provinces belong to. Each province has the same Gini value as the other provinces which they categorized in the same region with. For example, if the West Marmara region at Nuts1 level has 0.337 income Gini value, all the provinces located in this region such as Tekirdağ, Edirne, Kırklareli, Balıkesir, Çanakkale, are thought to have the same value, 0.337 . The same process is applied to the provinces at the Nuts2 level. 
Figure I: Income Gini of Nuts I level from 2006 to 2013

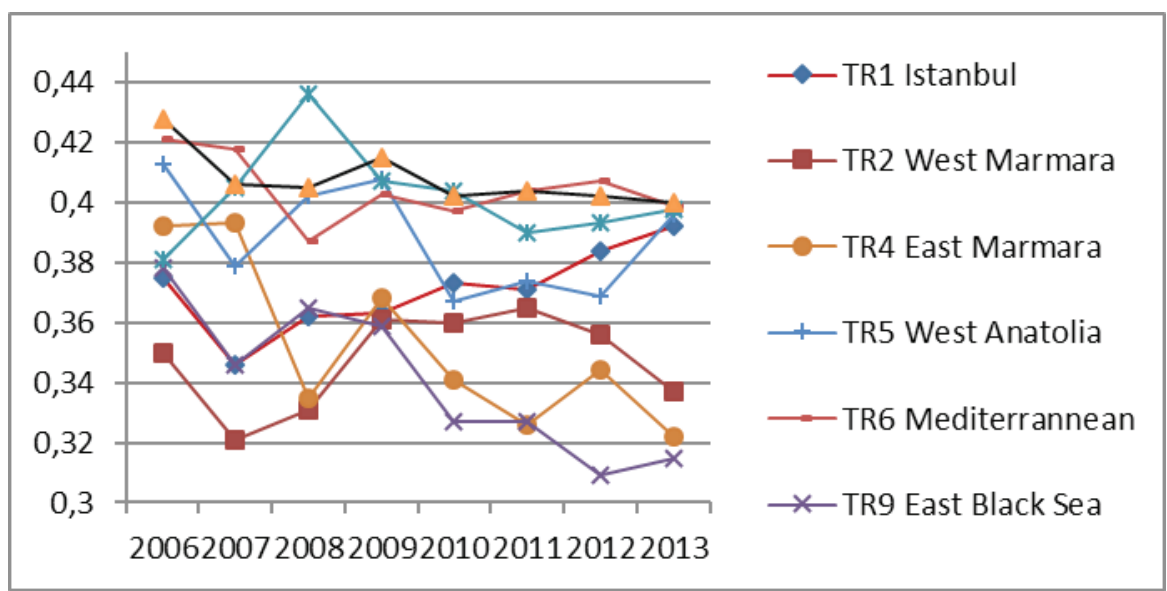

Source: TURKSTAT, Income and Living Conditions Survey.

As a measurement of inequality in education, educational Gini coefficient is calculated at the province level. The education levels that are used in the calculation are illiterate, literate without diploma, primary school, secondary school, high school, university degree, master and doctorate. Because of the difficulties in finding data, educational Gini coefficient is computed using completed education levels for population aged over 15. Data is obtained from TURKSTAT for the periods between 2008 and 2013. The calculation of educational Gini is based on the method of Thomas et al. ${ }^{17}$. The formula for the calculation is given below:

$G_{\bar{E}}=\left(\frac{1}{\mu}\right) \sum_{i=2}^{n} \sum_{j=1}^{i-1} p_{i}\left|y_{i}-y_{j}\right| p_{j}$

where $G_{E}$ is the Educational Gini, $\mu$ is the average years of schooling for the concerned population, $p_{i}$ and $p_{j}$ stand for the proportions of population with given levels of schooling, $y_{i} y_{i}$ and $y_{j}$ are the years of schooling at different education levels, $\mathrm{n}$ is the number of levels/categories in schooling data.

Descriptive statistics of educational Gini coefficients for each region is provided in Table 2 below. As it can be seen from the Table, educational Gini has also a downward trend between 2008 and 2013. The average of educational Gini for the period of analysis is 0.334 . While the average educational Gini value is 0.367 in 2008, it decreases to 0.312 in 2013 . However, as it can be seen from the Figure 2, some provinces which are located in Eastern and South-eastern Anatolia regions like Van, Şanlıurfa, Siirt, Muş, Diyarbakır, Ağrı have very high Gini values for education. In 2008, Şırnak has the highest Gini coefficient with a value of 0.536. On the other hand, in 2013, Ağr1 has the highest education inequality with a Gini index of 0.4114 . Furthermore, the lowest values of educational Gini generally belong to provinces in Marmara and relatively Central

17 Thomas V., Wang Y. and Fan X., "Measuring Education Inequality: Gini Coefficients of Education”, Policy Research Working Paper No: 2525. The World Bank, Washington, D.C., 2001. 
Anatolian regions such as Ankara, Bilecik, Bursa, Eskişehir, Kırklareli, Konya, Sakarya, Yalova. In 2008, Eskişehir has the most equally distributed education distribution with the lowest Gini value of 0.288 . However, Ankara, the capital city of Turkey, has the lowest educational Gini value in 2013. When İstanbul, the most populated city in Turkey, is analysed, the educational Gini of it seems relatively lower than the average value of the country with its average value of 6 years being 0.286 . Even, in 2013, it has one of the lowest values, 0.273 . These results are in line with Tomul ${ }^{18}$ 's findings for the period between 1975 and 2000, which shows that western regions of Turkey (İstanbul, Ankara, İzmir, Bursa) have the lowest education inequality compared with eastern regions (Mardin, Şanlıurfa, Ağrı, Van, Gaziantep) in these years.

Table 2: Descriptive statistics of educational Gini by year

\begin{tabular}{lccccc} 
Education Gini & Obs & Mean & Std. Dev. & Min & Max \\
\hline 2008 & 81 & 0,367 & 0,064 & 0,288 & 0,536 \\
2009 & 81 & 0,359 & 0,058 & 0,287 & 0,511 \\
2010 & 81 & 0,332 & 0,045 & 0,270 & 0,447 \\
2011 & 81 & 0,320 & 0,039 & 0,265 & 0,420 \\
2012 & 81 & 0,314 & 0,037 & 0,262 & 0,413 \\
2013 & 81 & 0,313 & 0,036 & 0,261 & 0,411 \\
\hline
\end{tabular}

Source: Authors' calculation based on ABPRS data.

Figure 2: Educational Gini of some provinces between 2008 and 2013

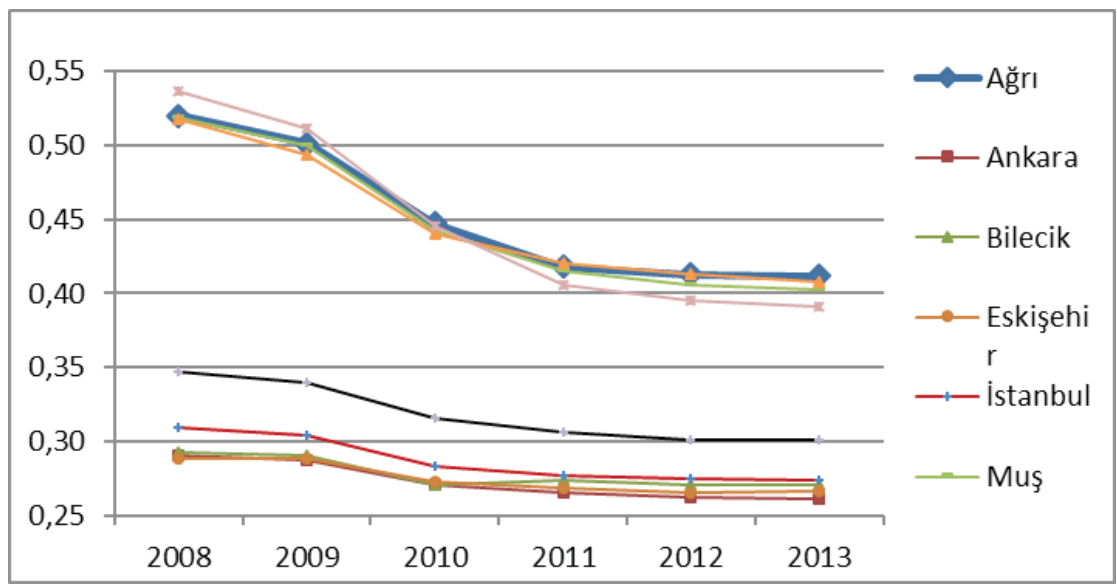

Source: Authors' calculation based on ABPRS data.

18 Tomul E., "Education Inequality in Turkey: An Evolution by Gini Index”, Education and Science, 2011, Vol. 36, No $160,2011$. 
In our analysis, we employ per capita value added data as a proxy for provincial income level as per capita GDP at the provincial level is not available in Turkey. Besides, we had to limit the analysis for the years between 2008 and 2011 as per capita value added is only available for those years from TURKSTAT. Per capita value added is measured in million TL and the sectorial discrimination is not included in data. Thus, it only shows the total per capita value added of all sectors. The original value added data is at the NUTS-2 level (26 regions). For that reason the data is expanded to provincial level by using the value for the provinces depending on the NUTS-2 region they belong to.

Labour force participation ratio is another variable which is thought to effect income (see Lopez, Thomas and Wang ${ }^{19}$ and O'Neill ${ }^{20}$ among others) and; therefore, it is included in the data assuming that it has an impact on income Gini as well. The data for this variable is at the provincial level and it is provided in percentages by the TURKSTAT.

While Castello and Domenech ${ }^{21}$ add the initial total years of schooling of population over 15 to their empirical model, Park ${ }^{22}$ and Gregorio and Lee ${ }^{23}$ choose the educational attainment values for analysing the effect of educational attainment on income Gini. By following the literature given above, number of students in secondary school by province is added to the empirical model.

Social expenditure is another significant issue that can affect income inequality. Income distribution seems more equally distributed in regions where social expenditure of government is larger (Gregorio and Lee ${ }^{24}$ ). Since we are trying to understand especially the role of education inequality on the income inequality, we included education expenditure per capita by province into our model. Education expenditures are measured in thousand TL and, the data is obtained from Ministry of Finance, General Directorate of Public Accounts for years between 2008 and 2013.

Some demographic variables of provinces such as male population ratio, crude divorce rate, number of births, crude marriage rate and crude suicide rate are included in the dataset at the provincial level to avoid the omitted variable bias as much as possible in addition to control for some province specific factors other than those that will be captured by province level fixed effects. All of these data are obtained from TURKSTAT between 2008 and 2013, and again at the province level.

\section{Empirical Analysis}

Higher education attainment and income are two different concepts, which actually affect each other ${ }^{25}$. Higher education attainment is directly related with education inequality, because

Lopez, Thomas and Wangi, Ibid.

O’Neill, Ibid.

Castello and Domenech, Ibid.

Park, Ibid.

Gregorio and Lee, Ibid.

Ibid.

Bils M. and Klenow P. J., “Does Schooling Cause Growth?” American Economic Review, 90(5), 2000, pp. 11601183. 
one can argue that if the education attainment gets higher, this would have an equalizing effect on education distribution. Therefore, it can be inferred that education inequality and income inequality do also affect each other. This means there could be a reverse causality problem between the dependent variable, income Gini index, and our main explanatory variable, education Gini index. Therefore, specification of an instrumental variable that is uncorrelated with error term but highly correlated with endogenous explanatory variable is the best way to get rid of simultaneity problem ${ }^{26}$.

The empirical analysis starts with basic static models of panel data methods. Pooled OLS and its modified version with the inclusion of time and regional fixed effects are the starting models. Then, fixed effects and random effects models in static form are applied to the dataset. To control the serial correlation between dependent variable and error terms, the analysis is continued by using dynamic models. Dynamic OLS, fixed effects, and first-difference methods are estimated. Since there is a reverse causality between income and education Gini indexes, AndersonHsiao and Arellano-Bond models are preferred as the most appropriate methods to eliminate simultaneity and serial correlation problems of the data. The standard errors in all static models are robust to the heteroscedasticity.

The first column in the Table 3 presents the results of pooled OLS estimation. Pooled OLS model without fixed effects finds no significant relationship between the educational and income inequality. When we add year and region fixed effects to the Pooled OLS model, we still find an insignificant though positive effect of education Gini on the income inequality. However, most of the regional dummies are significant except West Anatolia and Central Anatolia regions compared to reference region, İstanbul. The within-group regression results are shown in the third column. The education Gini coefficient is still statistically insignificant. The serial correlation of error terms is tested for this specification. Wooldridge test's null hypothesis of no first-order serial correlation is rejected for fixed effect estimation and the serial correlation is corrected by clustering the provinces. The forth model in the table gives the results for corrected within-group regression. After preventing the serial correlation in standard errors, it seems that the education Gini coefficient is still insignificant and the correction does not change the results. The last column of the Table 3 represents the results of random effects regression. The education Gini coefficient is again not significant in this model. It seems that potential endogeneity problem prevents us to reach a robust estimate. Besides, the serial correlation between dependent variable and error term violates the assumption of static models. Therefore, dynamic models are preferred to cope with these issued. By applying dynamic estimations, Nickell bias can also be controlled. The results of the different forms of dynamic models are shown in Table 4.

26 Baum C. F., An Introduction to Modern Econometrics Using Stata, Texas: Stata Press, 2006. 
Table 3: Static Model Estimations (Dependant Variable: In(Income Gini Index))

\begin{tabular}{|c|c|c|c|c|c|}
\hline Variable & $\begin{array}{r}\text { Pooled } \\
\text { OLS }\end{array}$ & $\begin{array}{l}\text { Pooled } \\
\text { OLS (2) }\end{array}$ & $\begin{array}{r}\text { Fixed } \\
\text { Effects }\end{array}$ & $\begin{array}{r}\text { Fixed Effects } \\
(2)\end{array}$ & $\begin{array}{r}\text { Random } \\
\text { Effects }\end{array}$ \\
\hline $\ln$ (Education Gini) & $\begin{array}{r}-0.022 \\
(0.050)\end{array}$ & $\begin{array}{r}0.018 \\
(0.033)\end{array}$ & $\begin{array}{r}-0.094 \\
(0.095)\end{array}$ & $\begin{array}{r}-0.094 \\
(0.095)\end{array}$ & $\begin{array}{r}-0.002 \\
(0.068)\end{array}$ \\
\hline $\ln$ (secschoolstudents) & $\begin{array}{r}0.023^{* * *} \\
(0.003)\end{array}$ & $\begin{array}{r}0.002 \\
(0.002)\end{array}$ & $\begin{array}{r}-0.020 \\
(0.044)\end{array}$ & $\begin{array}{r}-0.020 \\
(0.044)\end{array}$ & $\begin{array}{r}0.028^{* * *} \\
(0.005)\end{array}$ \\
\hline $\ln$ (pcexpenditure) & $\begin{array}{l}0.034^{* *} \\
(0.012)\end{array}$ & $\begin{array}{r}0.006 \\
(0.012)\end{array}$ & $\begin{array}{r}0.031 \\
(0.033)\end{array}$ & $\begin{array}{r}0.031 \\
(0.033)\end{array}$ & $\begin{array}{c}0.032^{*} \\
(0.015)\end{array}$ \\
\hline $\ln$ (pcvalueadded) & $\begin{array}{r}-0.139^{\star * *} \\
(0.016)\end{array}$ & $\begin{array}{r}-0.019 \\
(0.016)\end{array}$ & $\begin{array}{r}-0.231^{\star * *} \\
(0.049)\end{array}$ & $\begin{array}{r}-0.231^{\star * *} \\
(0.049)\end{array}$ & $\begin{array}{r}-0.159^{* * *} \\
(0.023)\end{array}$ \\
\hline $\ln$ (laborforce) & $\begin{array}{r}-0.001 \\
(0.027)\end{array}$ & $\begin{array}{r}0.093^{* * *} \\
(0.024)\end{array}$ & $\begin{array}{r}0.316^{* * *} \\
(0.045)\end{array}$ & $\begin{array}{r}0.316^{* * *} \\
(0.045)\end{array}$ & $\begin{array}{r}0.122^{* * *} \\
(0.032)\end{array}$ \\
\hline $\ln ($ suiciderate $)$ & $\begin{array}{r}0.048^{* * *} \\
(0.007)\end{array}$ & $\begin{array}{l}0.014^{* *} \\
(0.004)\end{array}$ & $\begin{array}{r}0.023^{* * *} \\
(0.005)\end{array}$ & $\begin{array}{r}0.023^{* * *} \\
(0.005)\end{array}$ & $\begin{array}{r}0.032^{* * *} \\
(0.005)\end{array}$ \\
\hline Constant & $\begin{array}{r}0.022 \\
(0.164)\end{array}$ & $\begin{array}{r}-1.195^{\star * *} \\
(0.154)\end{array}$ & $\begin{array}{r}0.009 \\
(0.643)\end{array}$ & $\begin{array}{r}0.009 \\
(0.643)\end{array}$ & $\begin{array}{r}-0.283 \\
(0.213)\end{array}$ \\
\hline Region fixed effects & NO & YES & NO & NO & NO \\
\hline Year fixed effects & NO & YES & NO & NO & NO \\
\hline $\mathrm{N}$ & 323 & 323 & 323 & 323 & 323 \\
\hline $\mathrm{R}^{2}$ & 0.470 & 0.861 & 0.296 & 0.296 & \\
\hline
\end{tabular}

Note: ${ }^{\star} \mathrm{p}<0.05,{ }^{* \star} \mathrm{p}<0.01$ and ${ }^{* * *} \mathrm{p}<0.001$

First of all, the simplest dynamic model, dynamic OLS is applied to the data. First-degree lagged value of income Gini variable is added to the model. Pooled OLS estimation results indicate that lagged income Gini variable has a significant and positive effect on income Gini coefficient. Education Gini coefficient is also statistically significant and, negatively correlated with income Gini coefficient. Since dynamic pooled OLS is the basic dynamic panel data method and cannot capture the individual effects, dynamic fixed effects model is applied. In the dynamic fixed effects model, all the variables seem insignificant except the education Gini which has negative effect on income Gini in this model. The results of dynamic random effects model are provided in the third column of the Table. The method has similar results with pooled OLS model. While the number of students in secondary school and per capita budget expenditure on education variables are insignificant, education Gini is in negative association with income Gini coefficient. First lagged value of income Gini has positive effect on income Gini. The fourth model is estimated by using first-differenced method. Differenced values of each variable are included in the model instead of the logarithm of real values. First-differenced model removes the individual effects by differencing it out. In this model, both lagged income Gini and education Gini are significant and have negative impact on income Gini. First-differenced method has correlation between error terms. Therefore, the model is specified as clustered in province level. 
Since education Gini index is suspected to be endogenous and, there is a reverse causality between education Gini and income Gini, As it is very difficult to find an instrument due to data availability, Anderson-Hsiao model is applied to control for both of these problems. First stage results of Anderson-Hsiao model show that the second lag of the income Gini is a good predictor of the lagged first difference. Thus, the first condition for it to be a valid instrument is satisfied. The instrumental variables regression results indicate that Anderson-Hsiao method estimates higher coefficients compared to first-difference model. However, the direction of the effects of both lagged difference of income Gini and differenced education Gini indices is the same as first-differenced method and, they are both negative. In addition, Anderson-Hsiao estimator is consistent but inefficient, as it does not make use of all the available information.

Lastly, Arellano-Bond model is applied to control both serial correlation between income Gini coefficient and error term and, the endogeneity problem. Only the lagged income Gini coefficient is added to the model. Education Gini has again statistically significant and negative impact on income Gini. The elasticity of income Gini with respect to education Gini is -0.386 . This means that a $1 \%$ increase in education Gini cause approximatetly a $38.6 \%$ decrease in the income Gini when the other variables held constant. The model also shows that lagged income Gini is significant and elasticity of it is -0.284 . The effect of labor force participation ratio on the income inequality is also statistically significant and, its elasticity is 0.101 . This shows that a $1 \%$ increase in the labor force participation ratio causes $10.1 \%$ increase in income Gini coefficient. However, it must be noted that although all these models mentioned above indicate the negative association between education Gini and income Gini coefficients however none of these models perfectly eliminates the serial correlation and endogeneity problems. Therefore, the results indicate a negative correlation rather than causality between education inequality and income distribution. 
Table 4: Dynamic Model Estimations (Dep. Variable: In(Income Gini Index))

\begin{tabular}{|c|c|c|c|c|c|c|}
\hline Variable & $\begin{array}{r}\text { Dynamic } \\
\text { OLS }\end{array}$ & $\begin{array}{r}\text { Dynamic } \\
\text { Fixed } \\
\text { Effects } \\
\end{array}$ & $\begin{array}{r}\text { Dynamic } \\
\text { Random Effects }\end{array}$ & $\begin{array}{r}\text { First- } \\
\text { Differences }\end{array}$ & $\begin{array}{r}\text { Anderson- } \\
\text { Hsiao }\end{array}$ & $\begin{array}{l}\text { Arellano- } \\
\text { Bond }\end{array}$ \\
\hline lagged $\ln$ (incomeGini) & $\begin{array}{r}0.704^{* * *} \\
(0.064)\end{array}$ & $\begin{array}{r}0.041 \\
(0.070)\end{array}$ & $\begin{array}{r}0.681^{* * *} \\
(0.065)\end{array}$ & & & $\begin{array}{r}-0.284^{* * *} \\
(0.057)\end{array}$ \\
\hline $\begin{array}{l}\text { Lagged diff } \\
\ln (\text { incomeGini) }\end{array}$ & & & & $\begin{array}{r}-0.135^{* *} \\
(0.049)\end{array}$ & $\begin{array}{r}-0.471^{* * *} \\
(0.134)\end{array}$ & \\
\hline $\ln$ (educationGini) & $\begin{array}{l}-0.092^{*} \\
(0.037)\end{array}$ & $\begin{array}{r}-0.428^{* * *} \\
(0.119)\end{array}$ & $\begin{array}{l}-0.094^{*} \\
(0.038)\end{array}$ & & & $\begin{array}{r}-0.386^{* *} \\
(0.118)\end{array}$ \\
\hline $\ln$ (secschoolstudents) & $\begin{array}{r}0.003 \\
(0.003)\end{array}$ & $\begin{array}{r}-0.063 \\
(0.054)\end{array}$ & $\begin{array}{r}0.004 \\
(0.003)\end{array}$ & & & $\begin{array}{r}-0.086 \\
(0.050)\end{array}$ \\
\hline $\ln$ (percapexpenditure) & $\begin{array}{r}-0.012 \\
(0.011)\end{array}$ & $\begin{array}{r}-0.053 \\
(0.053)\end{array}$ & $\begin{array}{r}-0.011 \\
(0.011)\end{array}$ & & & $\begin{array}{r}-0.059 \\
(0.041)\end{array}$ \\
\hline $\ln$ (pcvalueadded) & $\begin{array}{r}-0.046^{* *} \\
(0.016)\end{array}$ & $\begin{array}{r}-0.068 \\
(0.087)\end{array}$ & $\begin{array}{r}-0.050^{* *} \\
(0.017)\end{array}$ & & & $\begin{array}{r}0.012 \\
(0.086)\end{array}$ \\
\hline $\ln$ (laborforce) & $\begin{array}{r}-0.099^{* * *} \\
(0.023)\end{array}$ & $\begin{array}{r}0.071 \\
(0.062)\end{array}$ & $\begin{array}{r}-0.099^{* * *} \\
(0.023)\end{array}$ & & & $\begin{array}{r}0.101^{*} \\
(0.047)\end{array}$ \\
\hline $\ln$ (suiciderate) & $\begin{array}{r}0.028^{* * *} \\
(0.005)\end{array}$ & $\begin{array}{r}0.018^{* * *} \\
(0.004)\end{array}$ & $\begin{array}{r}0.029^{* * *} \\
(0.005)\end{array}$ & & & $\begin{array}{r}0.011^{* * *} \\
(0.003)\end{array}$ \\
\hline diff $\ln$ (educationGini) & & & & $\begin{array}{r}-0.407^{* * *} \\
(0.115)\end{array}$ & $\begin{array}{r}-0.490^{* * *} \\
(0.142)\end{array}$ & \\
\hline $\begin{array}{l}\text { diff } \\
\ln (\text { secschoolstudents })\end{array}$ & & & & $\begin{array}{r}-0.063 \\
(0.049)\end{array}$ & $\begin{array}{r}-0.106 \\
(0.055)\end{array}$ & \\
\hline diff $\ln ($ expenditurepc) & & & & $\begin{array}{l}-0.056 \\
(0.042)\end{array}$ & $\begin{array}{r}-0.059 \\
(0.044)\end{array}$ & \\
\hline diff $\ln$ (pcvalueadded) & & & & $\begin{array}{r}0.022 \\
(0.081)\end{array}$ & $\begin{array}{r}-0.106 \\
(0.119)\end{array}$ & \\
\hline diff $\ln$ (laborforce) & & & & $\begin{array}{r}0.092 \\
(0.046)\end{array}$ & $\begin{array}{c}0.143^{*} \\
(0.057)\end{array}$ & \\
\hline diff $\ln$ (suiciderate) & & & & $\begin{array}{r}0.012^{* * *} \\
(0.003)\end{array}$ & $\begin{array}{l}0.011^{* *} \\
(0.003)\end{array}$ & \\
\hline $\begin{array}{l}\text { Second lagged } \\
\ln \text { (incomeGini) }\end{array}$ & & & & & $\begin{array}{r}-0.447^{\star \star *} \\
(0.058)\end{array}$ & \\
\hline Year fixed effects & YES & YES & YES & YES & YES & YES \\
\hline $\mathrm{N}$ & 242 & 242 & 242 & 161 & 161 & 161 \\
\hline $\mathrm{R}^{2}$ & 0.746 & 0.468 & & 0.482 & . & \\
\hline
\end{tabular}

Note: ${ }^{\star} \mathrm{p}<0.05,{ }^{* *} \mathrm{p}<0.01$ and ${ }^{\star * *} \mathrm{p}<0.001$. 


\section{Conclusion}

This paper analysed the impact of the education inequality on income inequality in Turkey using a panel data at the provincial level. The analysis finds a negative relationship between education inequality and income inequality for the period between 2008 and 2011. Besides, the labor force participation ratio is positively correlated with income Gini index, as it is expected. As the labor force participation ratio increases by $1 \%$, the income Gini increases on average by $10.1 \%$, when the other variables remain constant.

The negative association between education Gini and income Gini gives some ideas about the possible policy suggestions that should be applied in the future. Higher educational inequality may imply both an increase in the number of high-skilled and low-skilled labour force and, thus, can result in a higher level of average years of schooling if the former increase dominates the latter. The negative impact of educational inequality on income inequality can be a result of this kind of a change. The data shows that the average schooling in Turkey increased through time and this could be one reason of a decrease in income inequality.

However, there is a room for an urgent structural reform in education as the average schooling level of Turkey is still so low and, therefore, income distribution has higher distortions. The highly educated people get higher salaries and the others with low education levels earn relatively lower salaries. These conditions increase the income inequality across the whole population. When the labour force becomes more educated, technological innovations would increase and this would accelerate the creation of more skilled jobs, which will increase the necessity for the low-skilled jobs as well. Higher demand for the low-skilled jobs will also result in increase in their wages due to their complementarity with the high-skilled population. In this sense, more people earn higher salaries and income inequality would decline. Therefore, the major policy concern for decrease of income inequality would be not only to increase of average schooling of the population but also to improve the quality of education to ensure the increase in economic development through technological improvements and innovation.

\section{References}

BAŞLEVENT C. and DAYIOĞLU M., "A Household Level Examination of Regional Income Disparity in Turkey", METU Studies in Development Journal, 32 (December), 2005, pp. 275-302.

BAUM C. F., An Introduction to Modern Econometrics Using Stata, Texas: Stata Press, 2006.

BILS M. and KLENOW P. J., "Does Schooling Cause Growth?” American Economic Review, 90(5), 2000, pp. 1160-1183.

CASTELLÓ A. and DOMÉNECH R., "Human Capital Inequality and Economic Growth: Some New Evidence", The Economic Journal. Vol. 112, No. 478, Conference Papers, 2002, pp. C187-C200.

CHECCHI D., "Education, Inequality and Income Inequality. Distributional Analysis", Research Programme Discussion Paper. No: DARP 52. The Toyota Centre, London, 2001.

DUMAN A.: Education and Income Inequality in Turkey: Does Schooling Matter?, Financial Theory and Practice. 32 (3), 2008, pp. 369-385. 
FÖLDVARI P. and VAN Leeuwen B., "Educational and Income Inequality in Europe, ca. 1870-2000", Cliometrica. 8, 2014, pp.271-300.

GREGORIO J. D. and LEE J.-W., "Education and Income Inequality: New Evidence from Cross-Country Data", Review of Income and Wealth. Series. 48, No. 3, 2002.

GÜNGÖR N. D. "Education, Human Capital Inequality and Economic Growth: Evidence from Turkey”, Regional and Sectoral Economic Studies, Vol. 10-2, 2010.

KAYAOGLU, A. and NAVAL J., "Urbanization, Education and the Growth Backlog of Africa", forthcoming.

LOPEZ R., Thomas V. and Wang Y., "Addressing the Education Puzzle: The Distribution of Education and Economic Reform”, Policy Research Working Paper No: 2031. The World Bank, Washington, D.C., 1998

OECD Factbook, Economic, Environmental and Social Statistics, OECD Publishing. OECD, Paris, 2014.

O’NEILL D., "Education and Income Growth: Implications for Cross-Country Inequality", Journal of Political Economy. Vol. 103, No. 6, 1995, pp. 1289-1301

PARK K. H., "Educational Expansion and Educational Inequality on Income Distribution, Economics of education Review", Vol. 15, No. 1, 1996, pp. 51-58.

SELİM R., GÜNÇAVDI Ö. and BAYAR A.A., "Türkiye’de Bireysel Gelir Dağılımı Eşitsizlikleri: Fonksiyonel Gelir Kaynakları ve Bölgesel Eşitsizlikler”, TÜSİAD Report No: TÜSİAD-T/2014-06/554. TÜSİAD, İstanbul, 2014.

THOMAS V., WANG Y. and FAN X., "Measuring Education Inequality: Gini Coefficients of Education", Policy Research Working Paper No: 2525. The World Bank, Washington, D.C., 2001.

TOMUL E., "Education Inequality in Turkey: An Evolution by Gini Index", Education and Science, 2011, Vol. 36, No 160, 2011.

World Bank: Introduction to Poverty Analysis, Working Paper No: 90288. World Bank, Washington, D.C., 2014.

YANIK B.: Türkiye'de Eğitim Eşitsizliği. Unpublished Master Thesis, ITU, İstanbul, 2001.

YANIK-İlhan B. and AYDINER-AVŞAR N., Education Inequality Among Working Age Population in Turkey: A Cohort Analysis, Emerging Patterns of Work and Turkish Labour Market Challenges under Globalization, Netherlands: Wolters Kluwer, 2013. 


\section{Appendix}

Table A. I: Descriptive statistics of all variables in 2008

\begin{tabular}{lccccc} 
2008 & Obs & Mean & Std. Dev. & Min & Max \\
\hline Income Gini & 81 & 0,377 & 0,031 & 0,331 & 0,436 \\
Education Gini & 81 & 0,367 & 0,064 & 0,288 & 0,536 \\
Per capita Value Added & 81 & 9659 & 3892 & 4379 & 18689 \\
Labor force & 81 & 47,209 & 8,616 & 26,900 & 66,300 \\
Divorce Rate & 81 & 1,163 & 0,589 & 0,120 & 2,690 \\
Births & 81 & 15978 & 27568 & 487 & 225910 \\
Marriage Rate & 81 & 9,198 & 1,344 & 6,580 & 13,360 \\
Suicide Rate & 81 & 4,496 & 1,887 & 1,540 & 14,330 \\
Male Pop Ratio & 81 & 0,504 & 0,012 & 0,488 & 0,575 \\
Sec School Pop Ratio & 81 & 0,030 & 0,007 & 0,019 & 0,051 \\
Per capita Exp & 81 & 1,280 & 0,493 & 0,714 & 3,597 \\
\hline
\end{tabular}

Table A.2: Descriptive statistics of all variables in 2009

\begin{tabular}{lccccc} 
2009 & Obs & Mean & Std. Dev. & Min & Max \\
\hline Income Gini & 81 & 0,390 & 0,019 & 0,359 & 0,415 \\
Education Gini & 81 & 0,359 & 0,058 & 0,287 & 0,511 \\
Per capita Value Added & 81 & 9737 & 3593 & 4846 & 18300 \\
Labor force & 81 & 48,779 & 7,746 & 30,400 & 65,800 \\
Divorce Rate & 81 & 1,313 & 0,646 & 0,140 & 2,740 \\
Births & 81 & 15618 & 25660 & 948 & 210170 \\
Marriage Rate & 81 & 8,341 & 1,166 & 6,280 & 11,670 \\
Suicide Rate & 81 & 4,346 & 1,707 & 1,330 & 12,980 \\
Male Pop Ratio & 81 & 0,504 & 0,011 & 0,492 & 0,569 \\
Sec School Pop Ratio & 81 & 0,032 & 0,008 & 0,018 & 0,059 \\
Per capita Exp & 81 & 1,513 & 0,639 & 0,800 & 5,329 \\
\hline
\end{tabular}


Table A.3: Descriptive statistics of all variables in 2010

\begin{tabular}{lccccc}
$\mathbf{2 0 1 0}$ & Obs & Mean & Std. Dev. & Min & Max \\
\hline Income Gini & 81 & 0,375 & 0,029 & 0,327 & 0,417 \\
Education Gini & 81 & 0,332 & 0,045 & 0,270 & 0,447 \\
Per capita Value Added & 81 & 10972 & 3850816 & 5575 & 20149 \\
Labor force & 81 & 49,409 & 6,198 & 31,800 & 61,800 \\
Divorce Rate & 81 & 1,340 & 0,659 & 0,140 & 2,820 \\
Births & 81 & 15534 & 26008 & 873 & 213378 \\
Marriage Rate & 81 & 7,969 & 1,034 & 5,820 & 10,740 \\
Suicide Rate & 81 & 4,298 & 2,030 & 0,610 & 16,310 \\
Male Pop Ratio & 81 & 0,504 & 0,012 & 0,490 & 0,570 \\
Sec School Pop Ratio & 81 & 0,035 & 0,009 & 0,020 & 0,068 \\
Per capita Exp & 81 & 1,760 & 0,825 & 0,898 & 6,803 \\
\hline
\end{tabular}

Table A.4: Descriptive statistics of all variables in 2011

\begin{tabular}{lccccc}
$\mathbf{2 0 1 1}$ & Obs & Mean & Std. Dev. & Min & Max \\
\hline Income Gini & 81 & 0,374 & 0,033 & 0,326 & 0,427 \\
Education Gini & 81 & 0,320 & 0,039 & 0,265 & 0,420 \\
Per capita Value Added & 81 & 12639 & 4671669 & 5894 & 23247 \\
Labor force & 81 & 50,683 & 6,667 & 30,600 & 62,500 \\
Divorce Rate & 81 & 1,306 & 0,658 & 0,110 & 2,820 \\
Births & 81 & 15366 & 25962 & 891 & 212241 \\
Marriage Rate & 81 & 7,912 & 0,965 & 6,090 & 10,360 \\
Suicide Rate & 80 & 3,882 & 1,586 & 0,620 & 11,270 \\
Male Pop Ratio & 81 & 0,505 & 0,013 & 0,490 & 0,576 \\
Sec School Pop Ratio & 81 & 0,034 & 0,008 & 0,021 & 0,065 \\
Per capita Exp & 81 & 2,027 & 0,831 & 1,113 & 5,948 \\
\hline
\end{tabular}


Table A.5: Descriptive statistics of all variables in 2012

\begin{tabular}{lccccc}
$\mathbf{2 0 1 2}$ & Obs & Mean & Std. Dev. & Min & Max \\
\hline Income Gini & 81 & 0,366 & 0,027 & 0,309 & 0,407 \\
Education Gini & 81 & 0,314 & 0,037 & 0,262 & 0,413 \\
Per capita Value Added & - & - & - & - & - \\
Labor force & 81 & 50,141 & 6,542 & 26,900 & 60,900 \\
Divorce Rate & 81 & 1,332 & 0,636 & 0,130 & 2,730 \\
Births & 81 & 15887 & 27493 & 913 & 225393 \\
Marriage Rate & 81 & 7,906 & 0,967 & 6,270 & 10,290 \\
Suicide Rate & 81 & 4,503 & 1,579 & 1,600 & 8,800 \\
Male Pop Ratio & 81 & 0,504 & 0,013 & 0,493 & 0,580 \\
Sec School Pop Ratio & 81 & 0,035 & 0,008 & 0,021 & 0,065 \\
Per capita Exp & 81 & 2,279 & 0,958 & 1,168 & 6,932 \\
\hline
\end{tabular}

Table A.6: Descriptive statistics of all variables in 2013

\begin{tabular}{lccccc}
$\mathbf{2 0 1 3}$ & Obs & Mean & Std. Dev. & Min & Max \\
\hline Income Gini & 81 & 0,359 & 0,030 & 0,315 & 0,399 \\
Education Gini & 81 & 0,313 & 0,036 & 0,261 & 0,411 \\
Per capita Value Added & - & - & - & - & - \\
Labor force & 81 & 50,527 & 5,511 & 36,200 & 62,800 \\
Divorce Rate & 81 & 1,343 & 0,615 & 0,140 & 2,700 \\
Births & 81 & 15840 & 27703 & 945 & 227162 \\
Marriage Rate & 81 & 7,740 & 0,936 & 6,140 & 10,120 \\
Suicide Rate & 81 & 4,405 & 1,407 & 0,740 & 9,330 \\
Male Pop Ratio & 81 & 0,504 & 0,010 & 0,494 & 0,558 \\
Sec School Pop Ratio & 81 & 0,038 & 0,007 & 0,026 & 0,063 \\
Per capita Exp & 81 & 2,596 & 1,040 & 1,240 & 7,823 \\
\hline
\end{tabular}

